\section{Cathepsin $A$ in Nutritional and Hereditary Muscular Dystrophy}

DurING the past few years, several laboratories ${ }^{1-8}$ have reported that the activities of many of the acid hydrolases of skeletal muscle are greatly increased in wasting diseases from different causes. Although the progressive loss of muscle mass in these conditions is generally attributed primarily to this enhanced activity of the acid hydrolases, there is little direct exporimental evidence in support of this hypothesis. Furthermore, other enzymes involved in protein catabolism, such as alkaline protease ${ }^{6}$ and peptidases ${ }^{9}$, have been shown to be elevated in dystrophic muscle. The normally low levels of these enzymes in skeletal muscle and the limited knowledge of their substrate specificities havo hindered a better understanding of the mechanism of the wasting process.

From skeletal muscle of rabbits and chickens we have isolated a highly purified protease ${ }^{10}$, similar in its properties to cathepsin $D$ of spleen ${ }^{11}$, which in liver has been shown to be localized in the lysosomes ${ }^{12}$. Unpublished data obtained with this purified enzyme freed of other known cathepsins show that it does hydrolyse certain muscle constituents but that, in itself, it cannot account for all the observed increase in dystrophic muscle autolysis.

This communication reports our finding that the activity of another proteolytic enzyme, cathepsin $A$, shown by Fruton and Bergmann to hydrolyse a number of peptides containing tyrosine or phenylalanine and glutamic acid ${ }^{13}$, $\mathrm{s}$ greatly increased in skeletal muscle of dystrophic animals.

Nutritional muscular dystrophy was produced in rabbits by feeding them a vitamin E-deficient $\operatorname{diet}^{14}$. Two types of control were used: animals maintained on the deficient diet but given oral supplements of DL- $\alpha$-tocopherol, and animals maintained on stock diets. There were no demonstrable differences in enzyme-levels in either type of control. Chickens with hereditary dystrophy ${ }^{15}$, and some controls, were raised from eggs supplied by the Department of Genetics, University of Connecticut; other controls were purchased from commercial suppliers. There was likewise no difference in enzyme-levels in either type of control. All chickens were 3-4 months old when used for these exporiments.

Cathepsin $A$ levels in breast muscle of the chicken and in mixed thigh, leg and back muscles of the rabbit were measured in a 2 per cent potassium chloride homogenate $(1: 4 \mathrm{w} / \mathrm{v})$ prepared in a Waring blender to which 'Triton $X-100^{\prime}$ had been added in a final concentration of 0.2 per cent. In experiments to be reported elsewhere, cathepsin $A$ has been found to be associated with the lysosomes isolated from liver and to be fully released under these conditions. The release of tyrosine due to the enzymatic hydrolysis of carbobenzoxy- $\alpha$-glutamyl-L-tyrosine (Mann Research Laboratories, Inc.) by cathepsin $A$ was determined by the ninhydrin colorimetric procedure of Moore and Stein ${ }^{16}$. There was no detectable non-enzymatic reloase of tyrosine under the assay conditions used, nor did the substrate itself react with ninhydrin. The reaction mixture, containing $0.4 \mathrm{ml}$. homogenate, $0.2 \mathrm{ml} .0 .2 \mathrm{M}$ sodium acetate, $p \mathrm{H} 5.0$, and $0.4 \mathrm{ml}$. $0.038 \mathrm{M}$ substrate or $\mathrm{H}_{2} \mathrm{O}$, was incubated at $37^{\circ}-38^{\circ} \mathrm{C}$ for $2 \mathrm{~h}$. The reaction was stopped by the addition of $1.0 \mathrm{ml}$. of 10 per cent trichloroacetic acid and the mixture was heated in a $50^{\circ}-55^{\circ} \mathrm{C}$ bath for $10 \mathrm{~min}$ and centrifuged for $15 \mathrm{~min}$ at low speed. The supernatant was diluted $1: 5$ with water. Aliquots of $0 \cdot 10-0 \cdot 20 \mathrm{ml}$. of the diluted supernatant were used for the colorimetric ninhydrin determination, with the appropriate lovel of tyrosine as a standard. Protein was estimated by the procedure of Lowry et al. ${ }^{17}$. The results are shown in Table 1.

The data indicate that the activity of cathepsin $A$ is significantly increased in both types of muscular dystrophy. It is noteworthy that the skeletal muscle of normal rabbits appears to be almost free of this protease,
Table 1. Cathepsin $A$ Agrivity in Dystrophic Muscle $\mu$ moles tyrosine liberated
per mg protein

Rabbit
Control (5)
Vitamin E-deficient (5)
Chicken
Control (7)
Dystrophic (8)

$0.012[0-0 \cdot 032]$

$0.197[0 \cdot 118-0 \cdot 371]$

$0 \cdot 126[0 \cdot 094-0 \cdot 170]$ $0 \cdot 292[0 \cdot 230-0 \cdot 365]$

The numbers in parentheses refer to the number of animals in that group and the square brackets enclose the range of values obtained.

whereas in the breast muscle of the chicken the level of this enzyme is comparatively high and approaches that seen in muscle of the vitamin E-deficient rabbit. The significance of these results in terms of the overall enzymatic hydrolysis of proteins in various species and in dystrophy cannot be evaluated until a more highly purified enzyme preparation, free of other cathepsins, has been obtained. Indeed, it is not yet known whether cathepsin $\boldsymbol{A}$ does actually have proteolytic activity or whether it is restricted in its action to the hydrolysis of small peptides. However, preliminary data obtained with a partially purifiod cathepsin $A$ preparation indicate that haemoglobin, at least, is not a good substrate for this enzyme.

Our present investigations with isolated cathepsin $A$, as well as other proteases, are directed toward the elucidation of the role of these enzymes in protein catabolism and a better understanding of the wasting process.

This work was supported by grants from the Muscular Dystrophy Associations of America, Ine., and the U.S. Public Health Service.

\section{A. A. IODICE}

I. M. Weinstock

Institute for Muscle Distase, Inc. New York.

1 Weinstock, I. M., Goldrich, A. D., and Milhorat, A. T., Proc. Soc. Exp. Biol. and Med., 88, 257 (1955).

${ }^{2}$ Weinstock, I. M., Epstein, S., and Milhorat, A. T., Proc. Soc. Exp. Biol. and Med., 99, $272(1958)$

${ }^{3}$ Zalkin, H., Tappel, A. L., Caldwell, K. A., Shibko, S., Desai, I. D., and Holliday, T. A., J. Biol. Chem 237,2678 (1962).

- Tappel, A. L., Zalkin, H., Caldwell, K. A., Desai, I. D., and Shibko, S., Arch. Biochem. Biophys., 96, 340 (1962).

5 Pellegrino, C., Villani, G., and Franzini, C., Arch. Sci. Biol. (Bologna), 41, $339(1957)$.

${ }^{6}$ Koszalka, T. R., Mason, K. E., and Krol, G., J. Nutrition, '73, 78 (1961).

' Weinstock, I. M., and Lukacs, M., Proc. Soc. Exp. Biol. and Med., 115, 716 (1964).

${ }^{8}$ Hajek, J., Gutmann, E., and Sytovy, I., Physiol. Bohemoslov, 13, 32 (1964)

- Wein, and Med., 91, 302 (1956).

${ }^{10}$ Iodice, A. A., and Weinstock, I. M., Fed. Proc., 23, 544 (1964).

${ }^{11}$ Press, E., Porter, R. R., and Cebra, J., Biochem. J., 74, 501 (1960),

12 De Duve, C., in Subcellular Particles, 128 (Ronald Press, New York, 1959).

13 Fruton, J. S., and Bergmann, M., J. Biol. Chem., 130, 19 (1939).

14 Goettsch, M., and Pappenheimer, A. M., J. Exp. Med., 54, 145 (1931).

${ }^{15}$ Asmundson, V. S., and Julian, L. M., J. Hered., 47, 248 (1956).

${ }^{16}$ Moore, S., and Stein, W. I., J. Biol. Chem., 211, 907 (1954).

${ }^{17}$ Lowry, O. H., Rosebrough, N. J., Farr, A. L., and Randall, R. J., J. Biol. Chem., 193, 265 (1951)

\section{HISTOLOGY}

\section{Visualization of the Nuclei of the Basal Melanocytes of the Black Guinea-pig and of Human Skin under the Bright Field Microscope}

The nuclei of the melanocytes isolated from the black guinea-pig and from human skin by the method of Shukla, Karkun and Mukerji ${ }^{1}$ are always masked by the dense melanin present in the cytoplasm (Figs. $1 A$ and $2 B$ ). A method to demelanize the cells and visualize the nuclei is reported here.

A saline suspension of melanocytes isolated by the technique of Shukla et al. from the skin of the dorsal surface of the black region of the ear of the spotted guinea-pig, or the peroneal surface of the leg of normally pigmented human subjocts, is mounted on albuminized slides and dried at $58^{\circ} \mathrm{C}$ in an oven. After an hour of drying the 